\title{
Help Wanted
}

\author{
By William Sugar
}

\section{Scenario}

Charles Brownback has been an adjunct professor in the Instructional Technology program at Shirebrook State University for 10 years. Charles received a BA in History and an MS in Video Production from Shirebrook State. After an internship at the state park's museum he opted for the public school track and became an 11th grade US history teacher at his alma mater, Shire High. Eventually, Charles decided to resign from that position to work full-time in his business, Brownback Productions.

When two senior faculty members opted for the university's generous early retirement program, Shirebrook hired two assistant professors to fill their faculty lines. Even with these new people, the Instructional Technology program needed an adjunct to teach the required Instructional Media course. Dr. Wellington, one of the retired faculty members, had taught this course for 25 years. The program identified Charles Brownback as the successor to take over Dr. Wellington's course.

Recently, Shirebrook's Education Dean contacted Ron Michaels, the Instructional Technology coordinator, about enhancing the program area's reputation. Dean Linden had attended a statewide ceremony where a high school senior received commendable recognition for her media production and an award. When talking with the student's principal, Dean Linden found out the school had transformed its graphics and industrial arts curriculum into a state-of-the-art media production and technologies curriculum. Student and parent interest had dramatically increased.
As a result, Dean Linden determined that Shirebrook needed to bulk up its media production emphasis. Ron Michaels was given an unambiguous directive to fully support a "media savvy" Instructional Technology faculty member to attend the next AECT conference in order to learn from as many professional development workshops as possible. By faculty consensus at a program meeting, Charles was the choice to be Shirebrook's representative.

In hindsight, going to AECT was a windfall for Brownback Productions. Though Charles spent ample time at AECT events, he also went to AECT's job board several times. During these visits, Charles successfully interviewed and subsequently hired an instructional media specialist for Brownback Productions.

Two faculty members discussed the new Brownback Productions employee at the program meeting. Doresia Winters lamented the fact that Charles did not hire a Shirebrook student. Since Charles essentially is an independent contractor with Shirebrook State, does he fall under the same ethical considerations as a fulltime faculty member? Charles' adjunct faculty status poses an intricate issue.

In-Sook Kim probed deeper. She thought that Charles should have exclusively focused on being a Shirebrook ambassador and should have separated his Brownback Productions agenda from this trip. Further, Charles' recent activities may pose an affront to this particular AECT principle:

\section{Principle}

\section{AECT Code of Professional Ethics \\ Section 3 - Commitment to the Profession}

\section{Principle 3}

In fulfilling obligations to the profession, the member shall avoid commercial exploitation of that person's membership in the Association.

(Apply the principle to the scenario for yourself before going on to read the analysis.)

\section{Analysis}

The impetus of Charles' funded trip to the AECT conference was to help Shirebrook's IT program develop and grow in media production. From Charles' perspective, the Brownback Productions hire was a bonus. To ensure that his business remains profitable, Charles needs to find the most qualified individuals for Brownback Productions.

Even though he was currently searching for an instructional media specialist, should he have stayed away from the AECT job board and exclusively focussed his attention on AECT activities relevant to his mission? Should he also have stifled his conversations about Brownback Productions during social events?

Dr. William Sugar is an associate professor and MS in Instructional Technology program coordinator in the department of Mathematics, Science, Instructional Technology Education at East Carolina University. 